\title{
Using contraception counseling to further improve adherence
}

\section{Fatema Zehra Juma Tamkin Abas}

Manchester Medical School, The University of Manchester,

Manchester, UK
Correspondence: Tamkin Abas Manchester Medical School,

The University of Manchester, Stopford Building, Oxford Road, Manchester, MI3 9PT, UK

Tel +44754284 245।

Email tamkin.abas@student.manchester. ac.uk
This article was published in the following Dove Press journal:

Open Access Journal of Contraception

13 October 2016

Number of times this article has been viewed

\section{Dear editor}

As medical students recently having done our Obstetrics and Gynecology placements, we feel the paper written by Rodriguez et $\mathrm{al}^{1}$ addresses a major issue within Gynecology. As mentioned by the authors, approximately half of the pregnancies are unintentional, either due to no contraception being used, poor compliance, or method failure. ${ }^{2,3}$

Rodriguez et al had reviewed the different modalities that could be used in counseling patients on contraception and how this has an impact on contraception uptake and adherence. We agree with their conclusion that a combination of modalities, such as including visual aids and utilizing social media, in addition to the clinician consultation is most effective. Using a combination of modalities allows patients to see the information multiple times, and as people have different learning styles, it increases the chances of their understanding and remembering the information. This enables clinicians to adopt a more patient-centered approach, working with patients to select contraception that is best suited to them, and thus most likely to be adhered to.

As well as using a patient-centered approach and utilizing multiple modalities to present information, we believe that a key issue not mentioned in this paper is emphasizing the importance of adherence to the patient through describing the differences in efficacy between "typical" and "perfect" use. It can be very reassuring for a patient to learn that their method of contraception is $>99 \%$ effective. ${ }^{4}$ However, this statistic is based on "perfect" use, and "typical" adherence is often much lower, with one study reporting that in oral contraception, $47 \%$ of users missed at least one pill per cycle and $22 \%$ missed two or more pills per cycle. ${ }^{5}$ As highlighted in the paper, there is a significant difference between "perfect" and "typical" use, with the efficacy of the combined oral contraceptive pill falling from $>99 \%$ to $91 \%{ }^{4}$ Presenting this difference to the patient during contraception counseling may be an effective way of highlighting the importance of and motivating patients to achieve "perfect" adherence.

Currently, information on the efficacy of different types of contraception is presented to patients and may be taken into account in their decision making. There is up to $6 \%$ difference in efficacy between the most common methods of contraception. ${ }^{4}$ However, when comparing the rate of efficacy between "perfect" and "typical" use for each method, there is more than $8 \%$ difference for oral contraception and $18 \%$ difference for male condoms. ${ }^{4}$ The more relevant information to take into account when trying to maximize 
efficacy may, therefore, be the difference in efficacy between "perfect" and "typical" use and the importance of aiming to achieve "perfect" use.

We believe that educating patients on the difference between "perfect" and "typical" use in contraception counseling may help to improve adherence, consequently reducing the rate of unintentional pregnancies.

\section{Disclosure}

The authors report no conflicts of interest in this communication.

\section{References}

1. Rodriguez J, Abutouk M Roque K, Sridhar A. Personalized contraceptive counseling: helping women make the right choice. Open Access $J$ Contracept. 2016;7:89-96.

2. Finer LB, Zolna MR. Shifts in intended and unintended pregnancies in the United States, 2001-2008. Am J Pub Health. 2014;104(Suppl 1):S43-S48.

3. Frost JJ, Darroch, JE, Remez L. Improving contraceptive use in the United States. Issues Brief (Alan Guttmacher Inst). 2008;(1):1-8.

4. Centers for Disease Control and Prevention. US selected practice recommendations for contraceptive use, 2013. MMWR Recomm Rep. 2013;62(RR05):1-60.

5. Rosenberg MJ, Waugh MS, Burnhill MS. Compliance, counseling and satisfaction with oral contraceptives: a prospective evaluation. Fam Plann Perspect. 1998;30(2):89-92, 104. 


\section{Authors' response}

Janelle Rodriguez

Mona Abutouk

Karen Roque

Aparna Sridhar

Department of Obstetrics and Gynecology, David Geffen School of Medicine at University of California Los Angeles, Los Angeles, CA, USA

Correspondence: Aparna Sridhar

Department of Obstetrics and Gynecology, David Geffen School of Medicine at University of California Los Angeles, 10833 Le Conte Ave, Los Angeles, CA 90095, USA

Email asridhar@mednet.ucla.edu

\section{Dear editor}

We thank Juma and Abas for their interest in our article, and we agree that this is an important issue while counseling couples about contraception. Information on the levels and trends in contraceptive use in the US is based on the National Survey of Family Growth, and periodic surveys conducted by the National Center for Health Statistics in which women aged 15-44 years are interviewed about topics related to child bearing, family planning, and maternal and child health..$^{1,2}$ Efficacy is one of the most important attributes of any contraception counseling discussion. We strongly encourage health care providers to use "typical use" failure rates during contraception counseling. Table 1 from the paper describes the differences between "typical" and "perfect" use. A recent article published in the popular New York Times based on the data by Dr James Trussel at the Office of Population Research at Princeton University also reflects the trends of change in effectiveness as women use contraceptive methods for a longer duration of time. ${ }^{3}$ This can be used to explain women about the "typical use" efficacy over time. We focused more on the counseling strategies in the paper and are happy to address any other concerns.

\section{Disclosure}

The authors report no conflicts of interest in this communication.

\section{References}

1. Daniels K, Daugherty J, Jones J, Mosher W. Current contraceptive use and variation by selected characteristics among women aged 15-44: United States, 2011-2013. Natl Health Stat Rep. 2015;(86):1-14.

2. Mosher WD, Jones J. Use of contraception in the United States: 19822008. National Center for Health Statistics. Vital Health Stat. 2010; 23(29). Available from: http://www.cdc.gov/NCHS/data/series/sr_23/ sr23_029.pdf. Accessed June 29, 2016.

3. New York Times. Aisch G, Marsh B. How Likely Is It That Birth Control Could Let You Down? Available from: http://www.nytimes.com/interactive/2014/09/14/sunday-review/unplanned-pregnancies.html?_r=0. Accessed July 19, 2016.

Dove Medical Press encourages responsible, free and frank academic debate. The content of the Open Access Journal of Contraception 'letters to the editor' section does not necessarily represent the views of Dove Medical Press, its officers, agents, employees, related entities or the Open Access Journal of Contraception editors. While all reasonable steps have been taken to confirm the content of each letter, Dove Medical Press accepts no liability in respect of the content of any letter, nor is it responsible for the content and accuracy of any letter to the editor.

\section{Publish your work in this journal}

Open Access Journal of Contraception is an international, peerreviewed, open access, online journal, publishing original research, reports, reviews and commentaries on all areas of contraception. In addition to clinical research, demographics and health-related aspects, the journal welcomes new findings in animal and preclinical studies relating to understanding the biological mechanisms and practical development of new contraceptive agents. The manuscript management system is completely online and includes a very quick and fair peer-review system. Visit http://www.dovepress.com/testimonials.php to read real quotes from published authors. 